Article

\title{
Treatment of Olive Mill Wastewater with Constructed Wetlands
}

\author{
Iosif E. Kapellakis ${ }^{1,2, *}$, Nikolaos V. Paranychianakis ${ }^{3}$, Konstantinos P. Tsagarakis ${ }^{4}$ and
} Andreas N. Angelakis ${ }^{1}$

1 Institute of Iraklio, National Agricultural Research Foundation, P.O. Box 2229, Iraklio 71307 , Greece; E-Mail: info@a-angelakis.gr

2 Kapellakis Technical and Real Estate Firm, Venerato Palianis, 70011, Greece

3 Department of Environmental Engineering, Technical University of Crete, Chania 73132, Greece; E-Mail: niko.paranychianakis@enveng.tuc.gr

4 Department of Environmental Engineering, Democritus University of Thrace, Xanthi 67100, Greece; E-Mail: kandila@her.forthnet.gr

* Author to whom correspondence should be addressed; E-Mail: kapellakis@teemail.gr; Tel.: +30-281-079-1948; Fax: +30-281-500-3399.

Received: 6 February 2012 / Accepted: 17 February 2012 / Published: 12 March 2012

\begin{abstract}
The objective of this study was to investigate the application of constructed wetlands as a mean to manage olive mill wastewater (OMW). Two free water surface (FWS) constructed wetlands, one without (CW1) and one with effluent recirculation (CW2), were operated for a two-year period with diluted OMW (1:10) and evaluated in terms of the removal of COD, TSS, TKN, $\mathrm{NH}_{4}{ }^{+}-\mathrm{N}, \mathrm{NO}_{3}{ }^{-}-\mathrm{N}, \mathrm{TP}$ and total phenols. The organic loading rate of CWs was adjusted to $925 \mathrm{~kg} \mathrm{BOD} / \mathrm{ha} \cdot \mathrm{d}$. In $\mathrm{CW} 1$ the removal efficiency averaged $80 \%, 83 \%, 78 \%, 80 \%$, and $74 \%$ for COD, TSS, TKN, TP, and total phenols, respectively, during the operation period. Effluent recirculation further improved the treatment efficiency which approached $90 \%, 98 \%, 87 \%, 85 \%$, and $87 \%$ for COD, TSS, TKN, TP, and total phenols, respectively. Constructed wetlands also showed high removal efficiency for $\mathrm{NH}_{4}{ }^{+}$-N. Nitrate concentration maintained low in both CWs basins, probably due to the prevalence of high denitrification rates that efficiently removed the $\mathrm{NO}_{3}{ }^{-} \mathrm{N}$ produced by $\mathrm{NH}_{4}{ }^{+}-\mathrm{N}$ oxidation. Despite the increased removal percentages, pollutant concentration in effluent exceeded the allowable limits for discharge in water bodies, suggesting that additional practices, including enhanced pre-application treatment and/or higher dilution rates, are required to make this practice effective for OMW management.
\end{abstract}


Keywords: effluent recirculation; free water surface constructed wetlands; nutrient removal; olive mill wastewater; organic load removal; phenols

\section{Introduction}

Olive mill wastewater (OMW), the liquid by-product generated during olive oil extraction, has been associated with severe environmental problems in the Mediterranean basin. These problems have been exacerbated during the last decades as a consequence of: (a) the increase in olive oil production, (b) the conversion of traditional olive oil mills $(\mathrm{OM})\left(3.25 \mathrm{~m}^{3} \mathrm{OMW} / \mathrm{tn}\right.$ of olive oil) into modern ones (centrifuge-type: $5 \mathrm{~m}^{3} \mathrm{OMW} / \mathrm{tn}$ of olive oil), (c) the dispersed location of a large number of low-capacity OM, and (d) the exclusion of OM personnel from the decision-making processes concerning OMW management [1]. To date, a large number of studies on various treatment methods have been published worldwide. Most of them deal with conventional treatment technologies, including anaerobic digestion, physico-chemical pre-treatments or advanced oxidation processes [2-4]. Some of them, although achieving effective treatment, are characterized by high operational costs and/or require experienced personnel. In addition, they place emphasis on certain constituents of OMW, mainly on organic matter, phenols and/or $\mathrm{pH}$ adjustment, without considering nutrients and salts, which are also associated with adverse ecological impacts. Currently, evaporation ponds are the most widely used practice to manage OMW, while land spreading to improve soil fertility is also practiced in some cases. Evaporation ponds provide a low cost technology; however they are associated with odor development, leaking of OMW to surface waterways or groundwater and relatively high area requirements in regions with low $\mathrm{ET}_{0}$ rates. An environmentally safe, cost-effective solution to OMW treatment has yet to be found.

Constructed wetlands $(\mathrm{CW})$ have been extensively used for many decades to treat wastewater from small, decentralized communities or to further polish effluents from conventional wastewater treatment plants [5]. During the last few years, CWs have been expanded to manage various types of wastes and polluted waters, including those of food-processing and livestock [6-8]. These effluents, similar to OMW, are characterized by high concentrations of organic matter and nutrients. To date, the use of $\mathrm{CW}$ as a potential means for OMW management has received little attention $[9,10]$. The restricted use of this practice in the Mediterranean region, where the major volume of global OMW production is produced, and its complex composition may be considered as probable reasons. However, data from the use of CWs to treat food-processing effluents show that they can operate effectively at high organic loading rates and produce effluent of high quality [8,11]. The aim of this work was to investigate the possibility of employing $\mathrm{CW}$ as an effective means for OMW management. The results of the operation for a two-year period of two free water surface (FWS) CW pilot basins, one with and one without effluent recirculation, are presented.

\section{Materials and Methods}

The study was carried out at the experimental field of the National Agricultural Research Foundation (NAGREF) in Skalani village, located $6 \mathrm{~km}$ south-east of Iraklio city, Crete, Greece. The 
operation of the CW occurred for two subsequent years: from June to October 2003, and from April to October 2004.

Raw OMW from a nearby OM was transferred and stored in a pond at the study area. During the operation period, OMW was transferred from the pond and diluted in a mixing tank (tank volume $=1.05 \mathrm{~m}^{3}$ ) with fresh water at a ratio of $1 / 10$. A hydraulic loading of $3.15 \mathrm{~m}^{3} / \mathrm{d}$ (three tanks) of diluted OMW, the composition of which is presented in Table 1, was applied on a daily basis at 00:00, 08:00, and 18:00 h (Figure 1). The two CW basins were operated under a sequencing batch feeding-day after day-regime: the first $24 \mathrm{~h}$ total quantity of influent was applied to $\mathrm{CW} 1$, while the second $24 \mathrm{~h}$ to $\mathrm{CW} 2$. This procedure was preferred to continuous flow, in order to know the exact amount of effluent applied in each CW basin. In order to investigate the effect of effluent recirculation on the overall performance of the CWs, $50 \%$ of the effluent in the second basin (CW2) was collected and reapplied on a daily basis.

Table 1. Composition of the mixed influent ( \pm SD).

\begin{tabular}{lcc}
\hline Parameters & Units & Diluted OMW \\
\hline $\mathrm{pH}$ & - & $6.93( \pm 0.45)$ \\
$\mathrm{EC}$ & $(\mathrm{dS} / \mathrm{m})$ & $4.18( \pm 0.90)$ \\
$\mathrm{COD}$ & $(\mathrm{g} / \mathrm{L})$ & $6.68( \pm 0.68)$ \\
$\mathrm{TSS}$ & $(\mathrm{mg} / \mathrm{L})$ & $2,362( \pm 204.71)$ \\
$\mathrm{TP}$ & $(\mathrm{mg} / \mathrm{L})$ & $43.65( \pm 15.81)$ \\
$\mathrm{In}-\mathrm{P}$ & $(\mathrm{mg} / \mathrm{L})$ & $14.85( \pm 1.77)$ \\
$\mathrm{TKN}$ & $(\mathrm{mg} / \mathrm{L})$ & $136.80( \pm 45.98)$ \\
$\mathrm{N}-\mathrm{NH}_{4}{ }^{+}$ & $(\mathrm{mg} / \mathrm{L})$ & $16.20( \pm 9.07)$ \\
$\mathrm{N}^{-} \mathrm{NO}_{3}{ }^{-}$ & $(\mathrm{mg} / \mathrm{L})$ & $3.60( \pm 0.97)$ \\
Total $_{\text {phenols }}$ & $(\mathrm{mg} / \mathrm{L})$ & $1,065( \pm 421.23)$ \\
\hline
\end{tabular}

Figure 1. The sequencing batch feeding and effluent recirculation for the two constructed wetlands $(\mathrm{CW})$ basins regime.

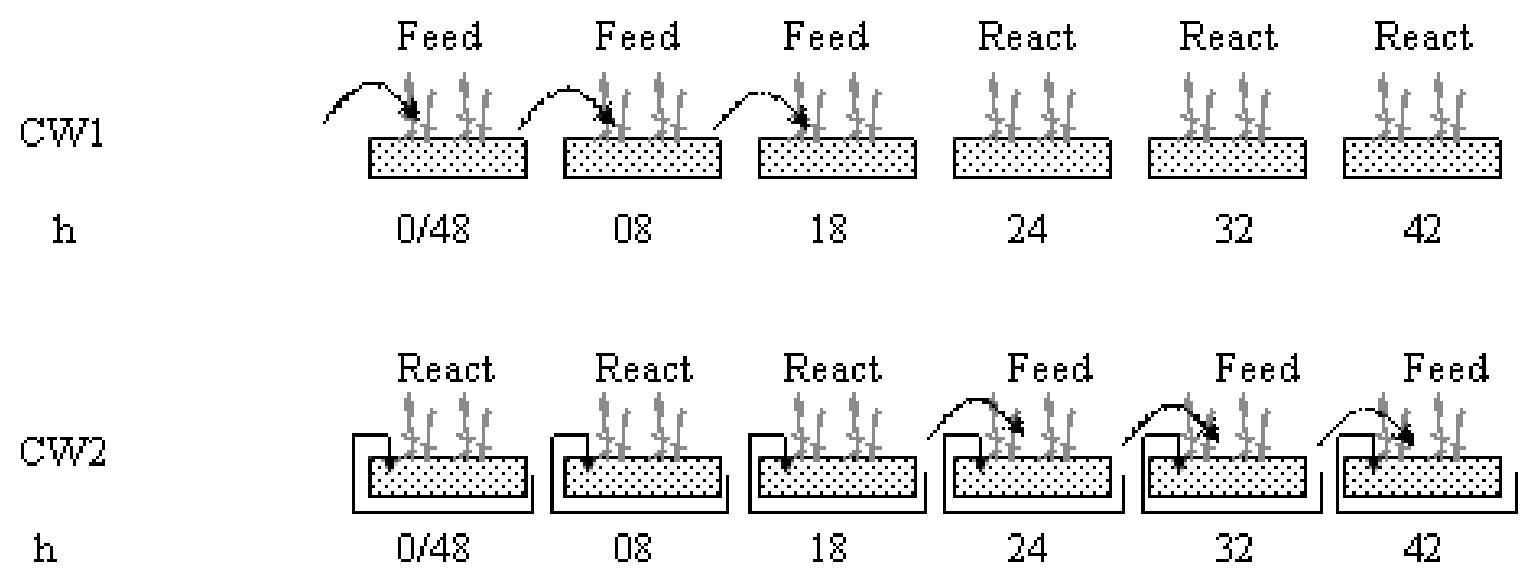


Each CW basin occupied an area of $45.5 \mathrm{~m}^{2}$ and had a length of $13 \mathrm{~m}$. Constructed wetland basins were thoroughly tested before adding the gravel to check for possible leakage. Coarse gravel of $0.5 \mathrm{~m}$ depth was used as a substrate material for vegetation. The depth of wastewater ranged from $0.15 \mathrm{~m}$ at the beginning of the basin to $0.25 \mathrm{~m}$ at the end. The theoretical retention time was calculated at 5 days. The basins were planted with Phragmites australis, selected because of its high tolerance to salts and phenols and its abundance in the Mediterranean Region. For a better distribution of organic load across the basins, wastewater was applied through nozzles in four pipes located at equal distances along them. The recirculation pipe was installed at the front side of CW2 (Figure 2).

Figure 2. Longitudinal-section of a basin.

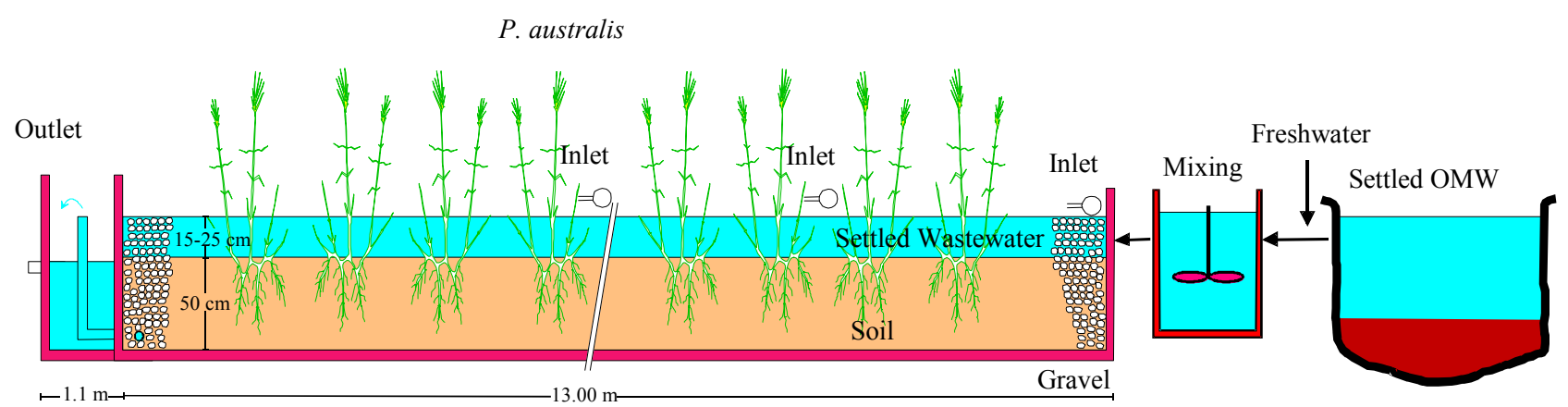

Samples of diluted OMW and effluents from CW1 and CW2 were collected fortnightly and analyzed for $\mathrm{pH}, \mathrm{EC}, \mathrm{COD}, \mathrm{TKN}, \mathrm{NH}_{4}{ }^{+}-\mathrm{N}, \mathrm{NO}_{3}{ }^{-}-\mathrm{N}, \mathrm{TP}$, and TSS. Preparation and analyses of the samples were carried out according to the Standard Methods for the Examination of Water and Wastewater [12]. Total phenols were assessed according to the Folin-Ciocalteu method [13].

A mass balance for $\mathrm{N}$ and $\mathrm{P}$ was applied during the second operation period by multiplying nutrient concentration with the total volume of OMW. Evapotranspiration (ET) losses were assessed by applying a simple hydrological balance at the entry and exit of wetland during this period.

\section{Results}

The monthly hydraulic loading of OMW applied to the two basins (CW1 and CW2) in the 2003 and 2004 operation periods is presented in Figure 3a. The cumulative loading was estimated to be $2,440 \mathrm{~mm}$ and $3,815 \mathrm{~mm}$ during the $1 \mathrm{st}$ and 2 nd operation years, respectively. The hydrologic balance was also calculated taking into account the losses of ET. It varied throughout the application period as a result of climatic conditions, and averaged to $38 \%$ of the applied OMW (Figure 3b).

Application of OMW in CWs resulted in a significant reduction in the concentration of all parameters investigated, as presented in Figures 4-6. In CW1 the average removal efficiency was estimated at $80 \%, 83 \%, 78 \%, 80 \%$, and $74 \%$ for COD, TSS, TKN, TP, and total phenols, respectively. The recirculation of OMW in CW2 further improved effluent quality with removal efficiency approaching $90 \%, 98 \%, 87 \%, 85 \%$, and $87 \%$ for COD, TSS, TKN, TP, and total phenols, respectively. With regard to the removal of $\mathrm{NH}_{4}{ }^{+}-\mathrm{N}$ and $\mathrm{NO}_{3}{ }^{-}-\mathrm{N}$, it was considerably lower compared to the other parameters monitored. The removal efficiency of $\mathrm{NO}_{3}{ }^{-}-\mathrm{N}$ approached $40 \%$ and $52 \%$ in the $\mathrm{CW} 1$ and $\mathrm{CW} 2$, respectively. The removal of $\mathrm{NH}_{4}{ }^{+}-\mathrm{N}$ was not affected by the recirculation and averaged to $54 \%$ in both wetland basins. The composition of the effluents leaving CWs is shown in Figures 3-6. 
Figure 3. (a) Monthly hydraulic loading of olive mill wastewater (OMW); (b) Weekly water balance for the second operational year.

(a)

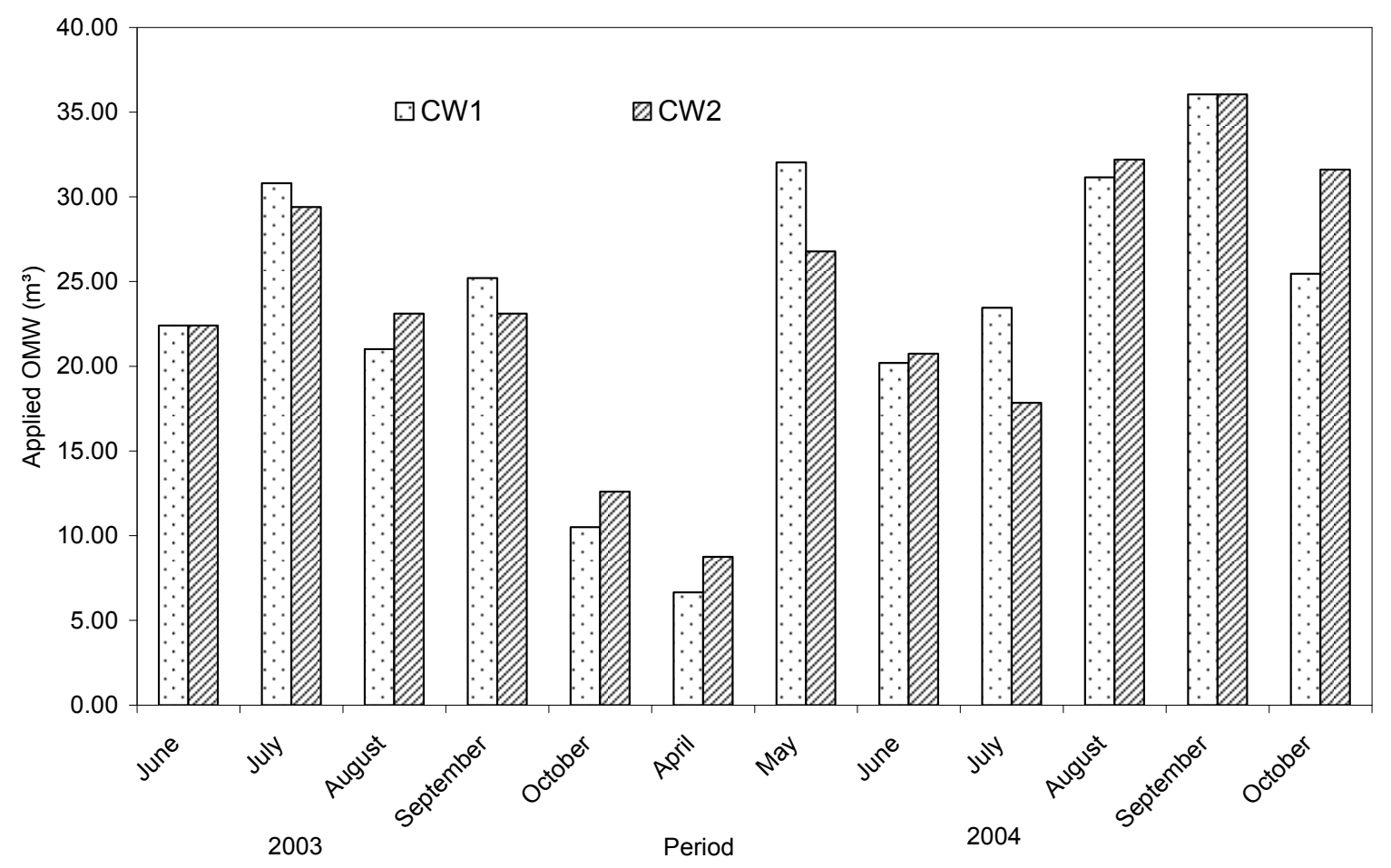

(b)

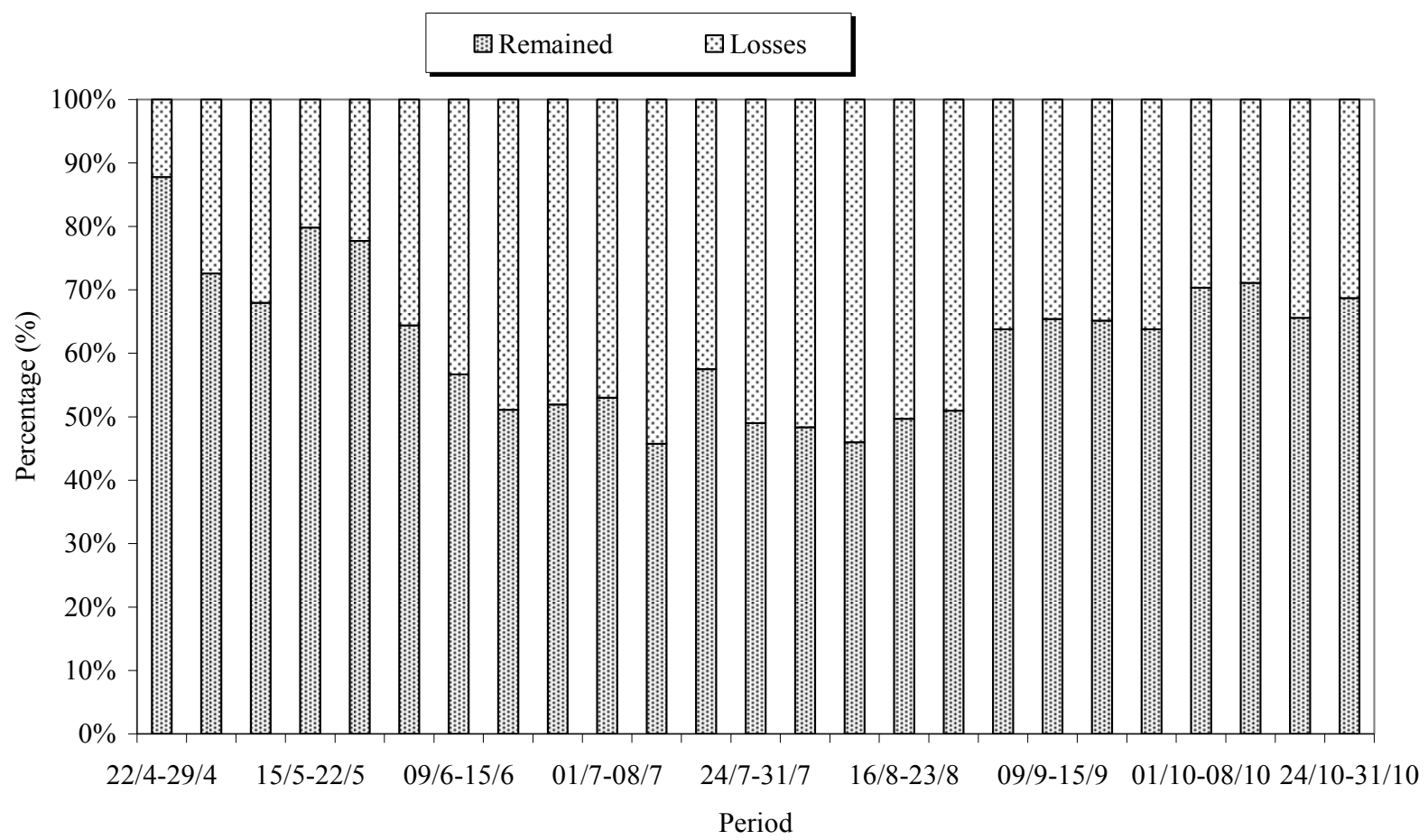


Figure 4. Average removal for (a) TSS $( \pm \mathrm{SD})$; (b) COD $( \pm \mathrm{SD})$; and (c) total phenols $( \pm \mathrm{SD})$.

(a)

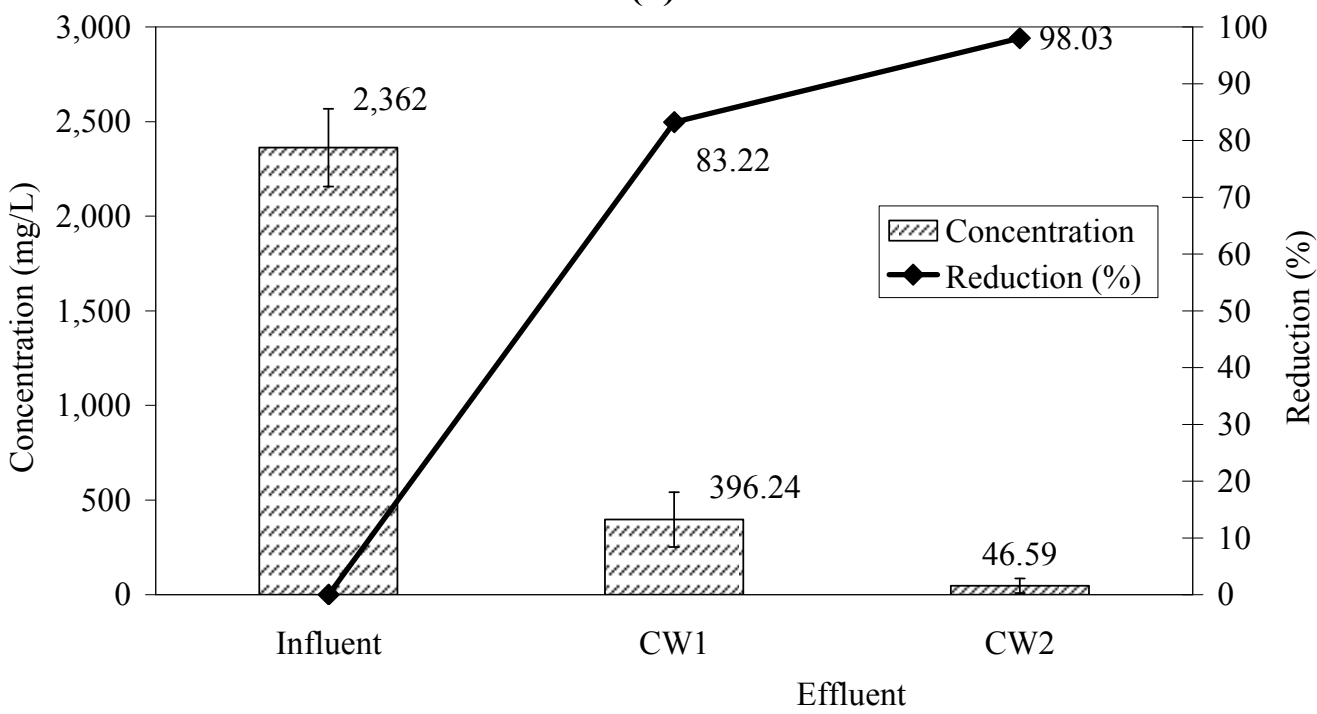

(b)

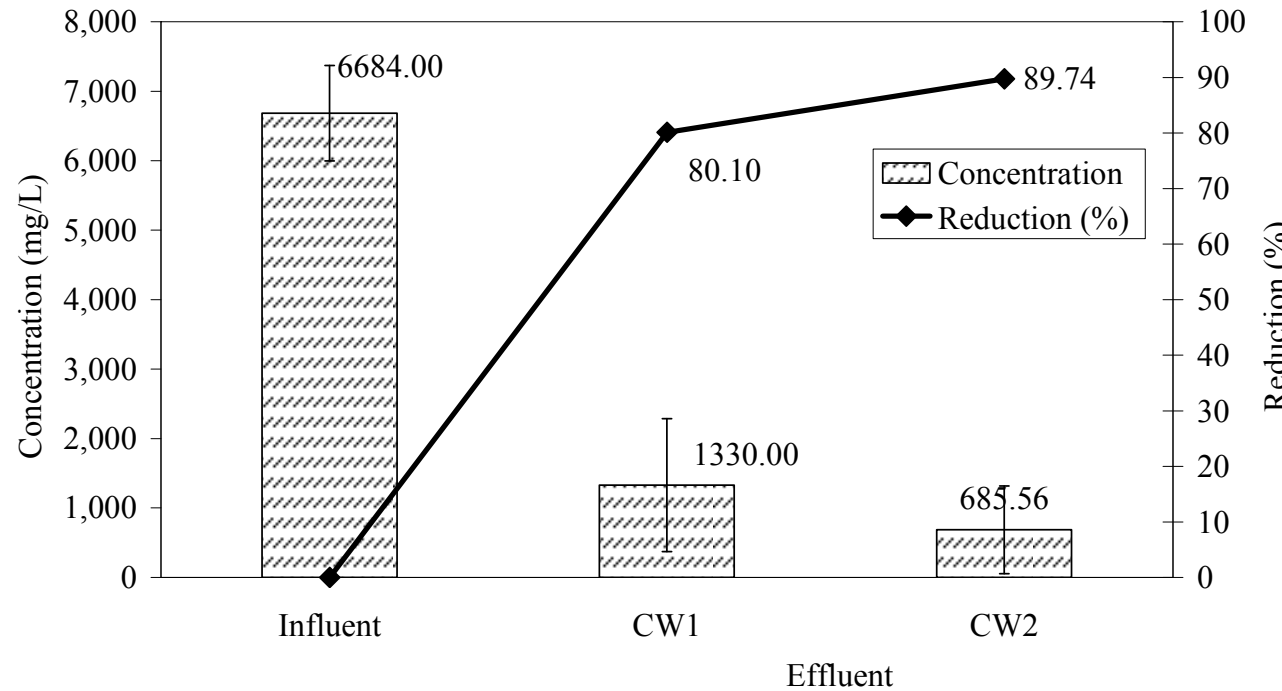

(c)

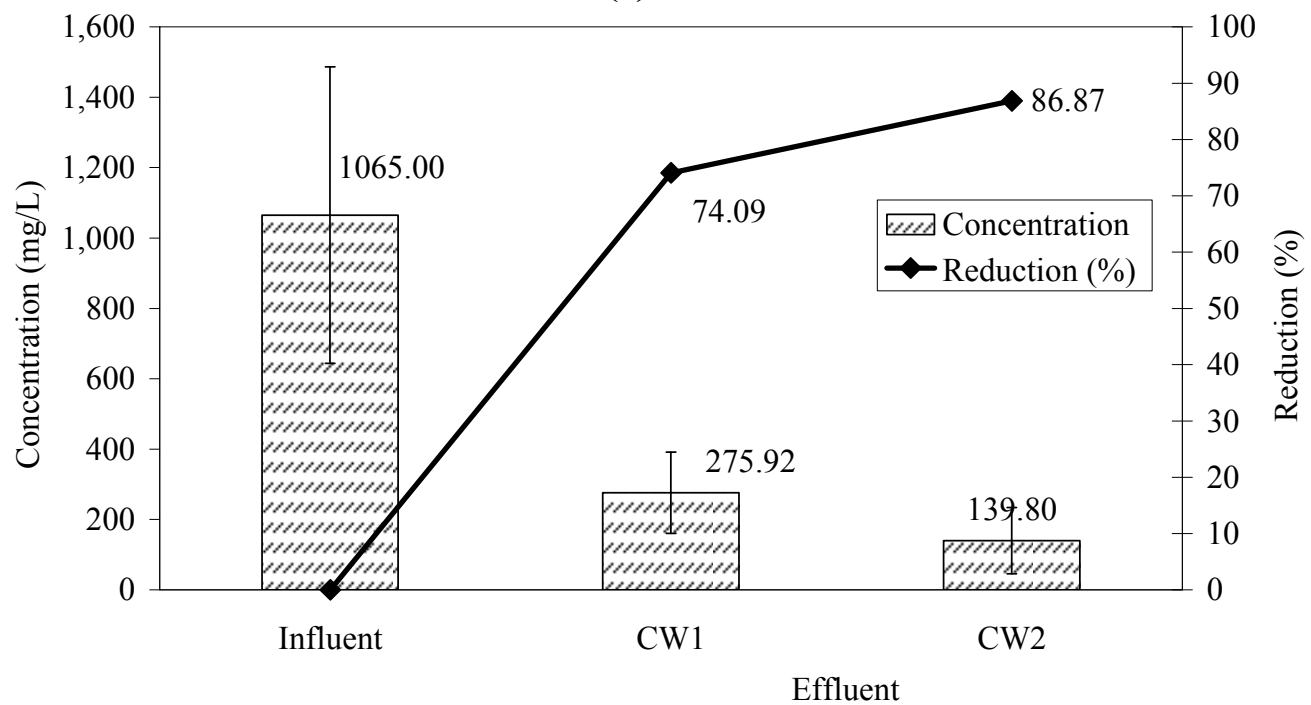


Figure 5. Average removal for (a) $\mathrm{TKN}( \pm \mathrm{SD})$ and (b) $\mathrm{TP}( \pm \mathrm{SD})$.

(a)

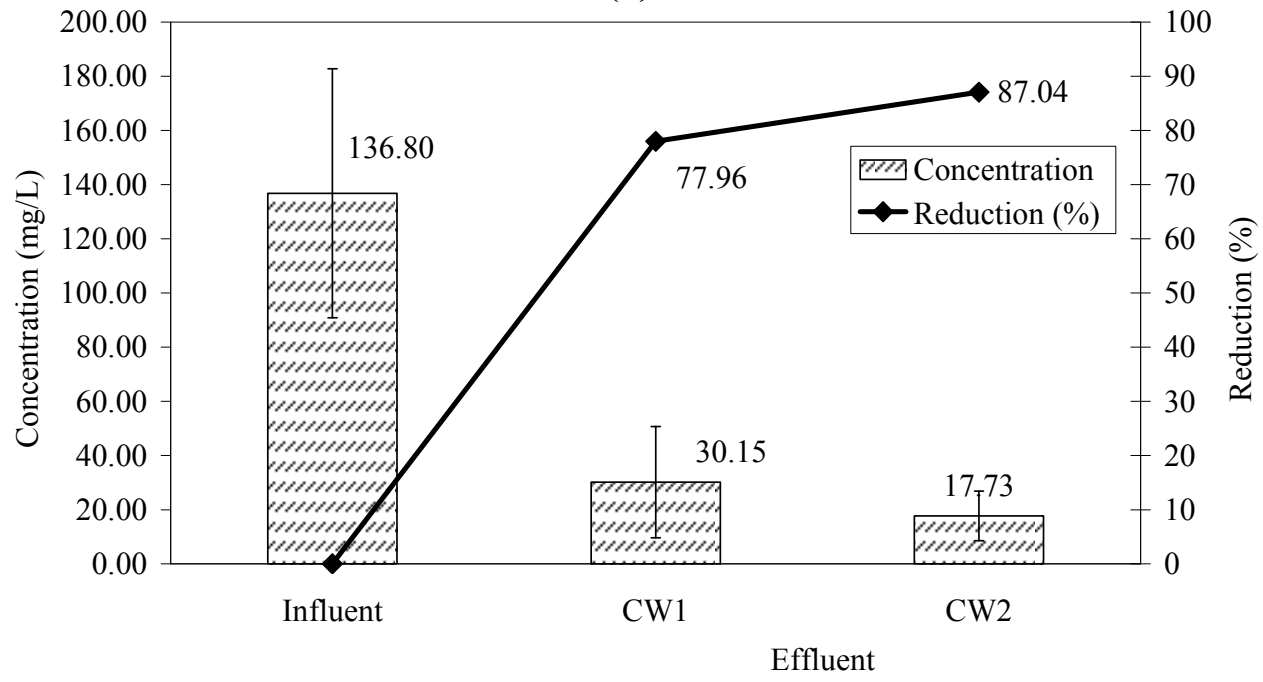

(b)

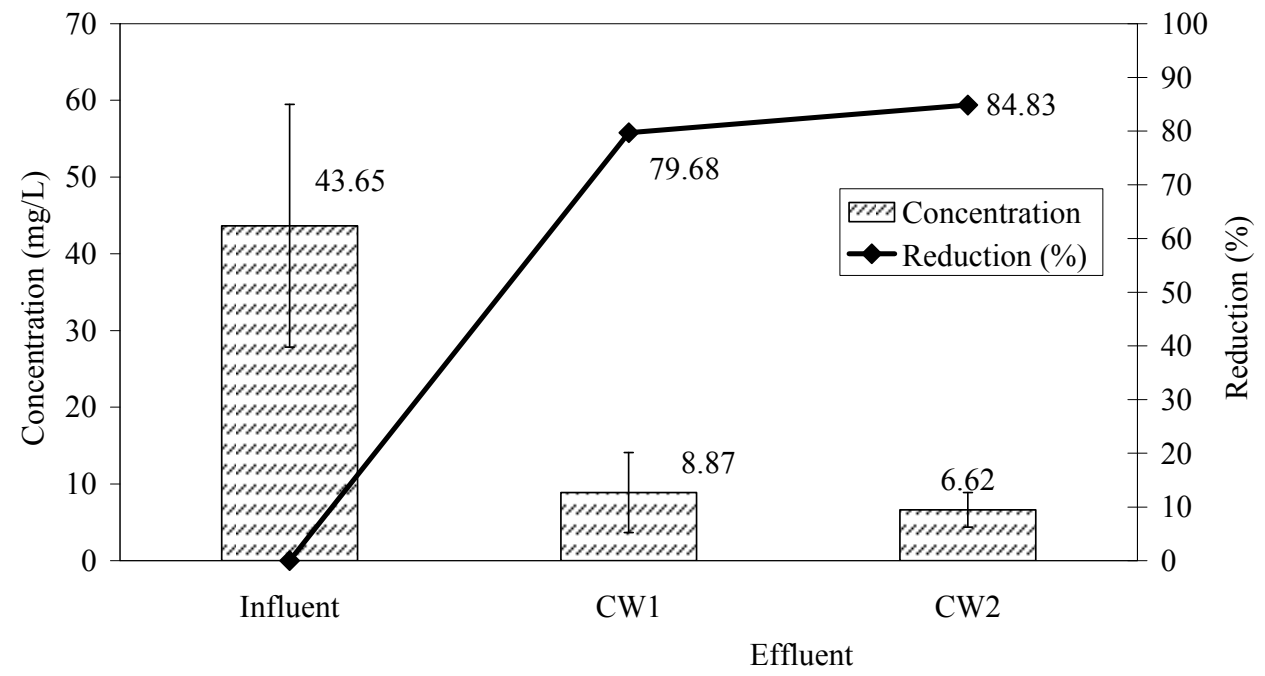

Figure 6. Average removal for (a) $\mathrm{NO}_{3}{ }^{-} \mathrm{N}( \pm \mathrm{SD})$ and (b) $\mathrm{NH}_{4}{ }^{+}-\mathrm{N}( \pm \mathrm{SD})$.

(a)

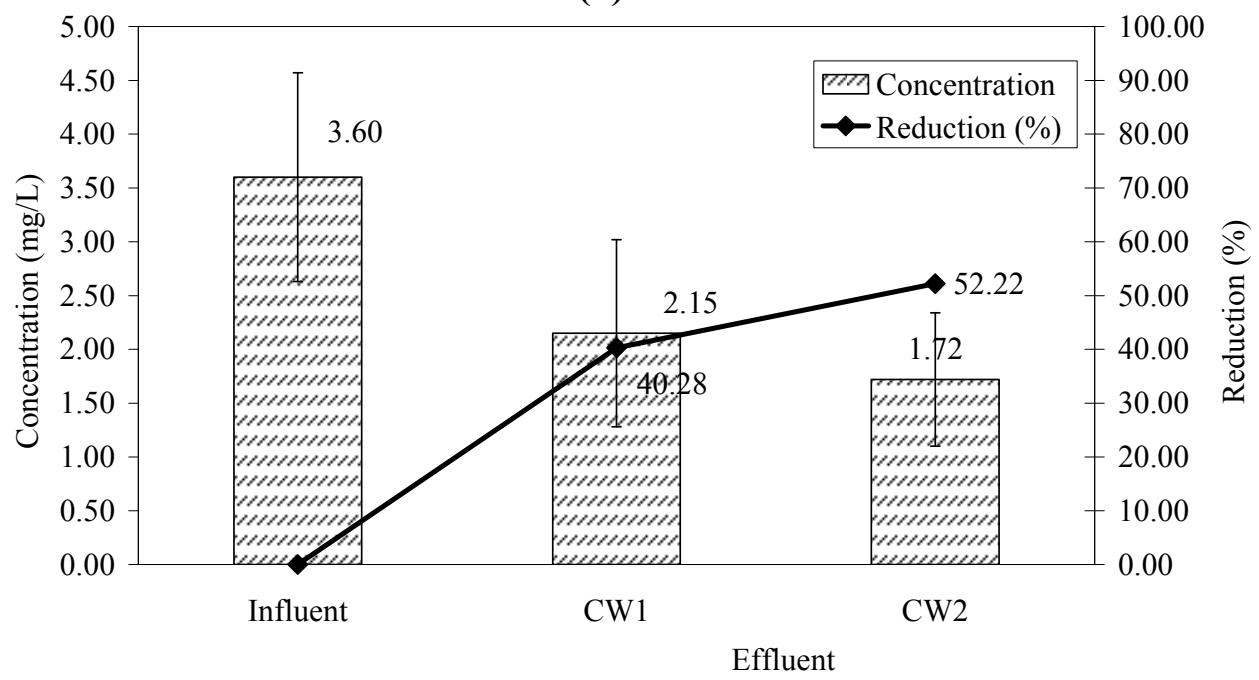


Figure 6. Cont.

(b)

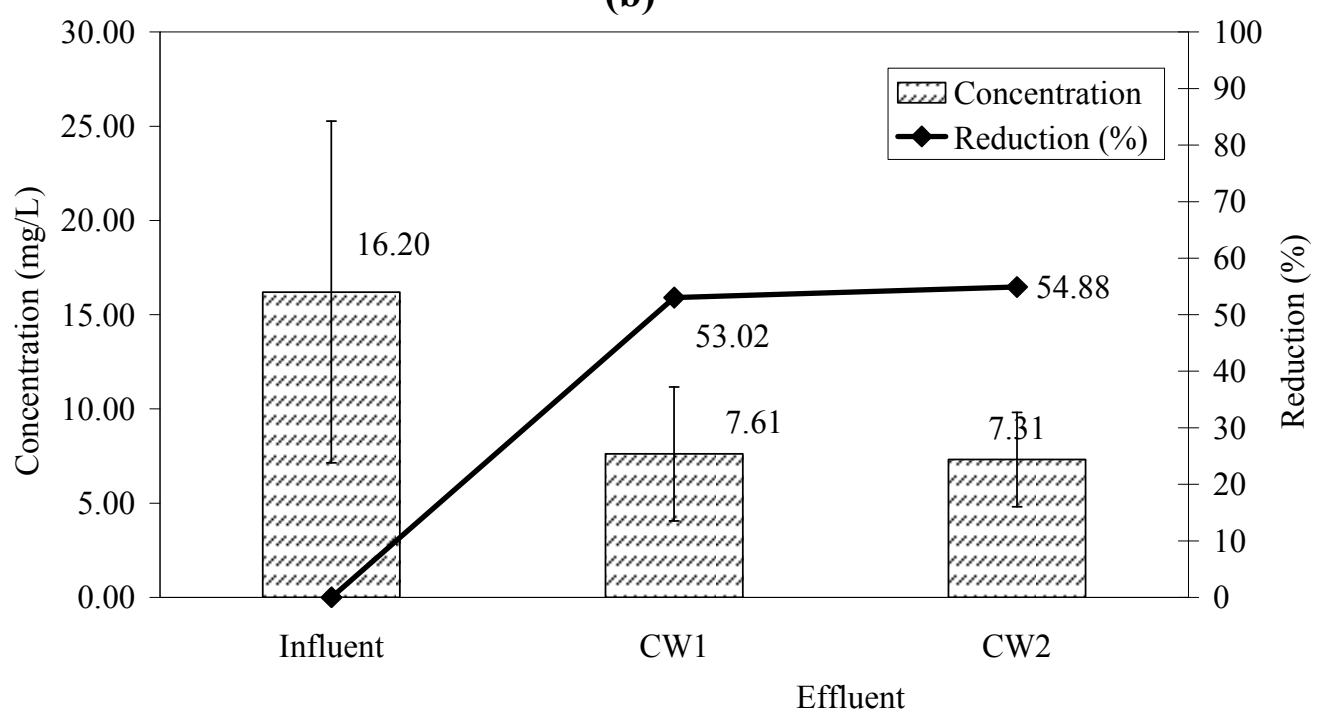

A mass balance was established in the second year of operation to calculate the mass removal of the pollutants during this period. The findings revealed a greater removal efficiency compared to that estimated by the decrease of pollutant concentration. This discrepancy is attributed to the effect of ET which concentrated effluent and thus increased pollutants concentration. The mass removal rate of TSS increased from $43.20 \mathrm{~g} / \mathrm{m}^{2} \cdot \mathrm{d}$ in CW1 to $50.90 \mathrm{~g} / \mathrm{m}^{2} \cdot \mathrm{d}$ in CW2. The corresponding mass removal rate of COD was estimated to 117.7 and $131.8 \mathrm{~g} / \mathrm{m}^{2} \cdot \mathrm{d}$ for $\mathrm{CW} 1$ and $\mathrm{CW} 2$, respectively. Compared to COD, the percentage of phenol mass removal rates was lower and estimated at $17.34 \mathrm{~g} / \mathrm{m}^{2} \cdot \mathrm{d}$ and $20.33 \mathrm{~g} / \mathrm{m}^{2} \cdot \mathrm{d}$ for CW1 and CW2, respectively. Ammonium and nitrates showed significantly lower percentages of mass removal. These were found to be 0.032 and $0.041 \mathrm{~g} / \mathrm{m}^{2} \cdot \mathrm{d}$ for $\mathrm{NH}_{4}{ }^{+}-\mathrm{N}$ in $\mathrm{CW} 1$ and CW2, respectively, and $0.19 \mathrm{~g} / \mathrm{m}^{2} \cdot \mathrm{d}$ and $0.20 \mathrm{~g} / \mathrm{m}^{2} \cdot \mathrm{d}$ for $\mathrm{NO}_{3}{ }^{-}-\mathrm{N}$ in $\mathrm{CW} 1$ and $\mathrm{CW} 2$, respectively.

\section{Discussion}

Olive mill wastewater is characterized by extremely high concentrations of organic matter and phenols and very low $\mathrm{pH}$ values [14]. These characteristics, in combination with the dispersion of a large number of low-capacity OM units, limit the potential solutions for OMW management and make the task of finding an appropriate treatment method difficult. CWs are suitable for decentralized wastewater management due to low costs of construction, operation and maintenance [15]. They have been effectively employed in the treatment of food-processing effluents [8], thus providing evidence for potential use in OMW management. However, the composition of raw OMW precludes its direct use in constructed wetlands, since adverse effects may occur to impair the treatment performance. These include the prevalence of anaerobic conditions, odor development, death of vegetation, and limited or no outflow. A pre-application treatment and some dilution of the raw OMW are therefore a prerequisite in order to avoid or at least reduce the adverse effects of the previously mentioned factors. A dilution of 1/10 with fresh water was applied in this study, as it was calculated as the minimum dilution necessary to ensure wastewater volumes for the viable operation of the CWs and to avoid detrimental effects on vegetation. The same dilution ratio was also used in a subsurface horizontal flow wetland operated with OMW after pretreatment of effluent with lime putty, calcium hydroxide and 
hydraulic lime [9]. Indeed, course of this study no visual signs of toxicity were observed for $P$. australis, an effect consistent with the excellent ability of this species to tolerate stressful conditions [16,17].

The 1/10 dilution of OMW resulted in approximately $925 \mathrm{kgBOD} / \mathrm{ha} \cdot \mathrm{d}$ loading, considering a $\mathrm{BOD} / \mathrm{COD}$ ratio $1 / 2.5$ which assessed in preliminary measurements, which is among the maximum loads reported in the literature $[6,11,18]$. Despite these extreme loads, CWs showed high removal efficiencies in terms of TSS, COD, TKN, and phenols. Effluent recirculation further improved treatment efficiency of CWs, an effect attributed to the additional $\mathrm{O}_{2}$ supply entered into the basin. This is an important consideration when using high strength wastewaters to improve treatment performance and to avoid the occurrence of anoxic/anaerobic conditions. The mass removal rate of COD approached $130 \mathrm{~g} / \mathrm{m}^{2} \mathrm{~d}$ on average. Similar or higher removal rates of COD (120 to $250 \mathrm{~g} / \mathrm{m}^{2}$ ) have been also reported by Grismer [6] for a CW operated with winery effluent. Compared to COD, the percentage of phenol removal was lower in CW1 but reached similar levels in CW2, revealing that $\mathrm{O}_{2}$ availability and probably antagonistic effects among the microorganisms performing the mineralization of organic compounds were the limiting factors. Decreasing COD concentrations in the effluent was found to favor the removal of phenols, an effect that can be attributed to the increase in dissolved $\mathrm{O}_{2}$ availability and the decrease in the availability of more biodegradable substances than phenols [19]. This finding provides important implications for the management of CWs operated with OMW in terms of phenol removal, the constituent associated with the high toxicity of OMW. Thus, based on the findings of the present study, it can be assumed that applying a higher dilution ratio, increasing retention time and/or effluent recirculation in CW basin, the removal efficiency of CWs is expected to be improved. Despite these high removal rates, effluent concentrations of COD and phenols remained above the levels required for discharge, suggesting that additional treatment is required. However, taking into consideration the increasing number of studies dealing with land spreading of OMW [20-23] and the beneficial effects of controlled application of OMW on soil fertility, CWs could be employed as a pretreatment step to ameliorate the potential adverse effects of OMW before its recycling to the land.

TKN removal followed a removal pattern similar to that of COD. Removal of COD and TKN is not necessarily attributed to the degradation of organic matter, since settling of suspended solids is expected to have also an important contribution. With the progress of time, however, settled particulate organic matter is expected to be biodegraded and increasingly contribute to $\mathrm{NH}_{4}{ }^{+}-\mathrm{N}$ release. $\mathrm{NH}_{4}{ }^{+}-\mathrm{N}$ accumulation was not observed in either basin, in contrast to the results from the majority of studies dealing with effluents with high organic-N [24]. A high potential of vertical type CWs to remove $\mathrm{NH}_{4}{ }^{+}-\mathrm{N}$ from OMW, up to $70 \%$, was recently indicated [10]. Since effluent $\mathrm{pH}$ did not favor the volatilization of significant amounts of $\mathrm{NH}_{3}$, the findings of this study probably suggest absorption of $\mathrm{NH}_{4}{ }^{+} \mathrm{N}$ to the gravel and basin walls. Oxidation to $\mathrm{NO}_{3}{ }^{-}-\mathrm{N}$ is not expected to occur at high rates due to the limited $\mathrm{O}_{2}$ availability and the excess of organic matter, given that under such conditions the available $\mathrm{O}_{2}$ is preferentially utilized by the microorganisms which mineralize the organic material decreasing the activity of nitrifiers [25]. It cannot precluded however the occurrence of microsites which favor nitrification. In addition, it can be assumed that the redox conditions in CWs operated with a high organic load favor partial nitrification which could be coupled with anammox process contributing in $\mathrm{N}$ removal. Recent works showed that anammox process may have a significant 
contribution in $\mathrm{N}$ cycling in CWs, estimated in the range of 15 to $33 \%$ of the emitted $\mathrm{N}_{2}$ [26-28]. Apparently, more work is needed to quantify the contribution of denitrification and anammox in constructed wetlands. The removal of nitrates in CWs is mainly attributed to denitrification [25,29]. Effluent recirculation in this study did not affect the removal of nitrates, since carbon was not a limiting factor and anoxic conditions prevailed during the operation of wetlands.

\section{Conclusions}

Free water surface constructed wetlands showed a high potential for the removal of TSS, COD, organic matter, $\mathrm{NH}_{4}{ }^{+}-\mathrm{N}$ and phenols. Despite high rates of removal, approaching $90 \%$ for COD and phenols, concentration in the effluents remained above the accepted limits for stream discharge. However, CWs can be considered as a pretreatment step to ameliorate the potential adverse effects of OMW before being recycled to the land, a common practice in many Mediterranean countries. The findings of this study show that the factor limiting the performance of the $\mathrm{CW}$ was the high organic loading rates applied which depleted the available $\mathrm{O}_{2}$. Use of a greater dilution ratio for OMW, increase of the surface area of CWs or mechanical supply of $\mathrm{O}_{2}$ could be considered as potential strategies to improve system performance. However, these would inevitably increase installation and operational costs. To overcome these constraints, a number of considerations should be taken into account in later studies including: (i) the use of hybrid CW systems to increase $\mathrm{O}_{2}$ availability, (ii) the assessment of the optimum dilution ratio to minimize the interactions among the microorganisms performing the degradation of pollutants, and (iii) the investigation of the mechanisms involved in $\mathrm{N}$ cycling.

\section{Acknowledgments}

This study is dedicated to the memory of Iosif A. Papadakis. This work was partially supported by the EU-research project INCO 517612 (MELIA). The authors are grateful to V. Tzanakakis and M. Titakis for their critical comments and help during this study.

\section{References and Notes}

1. Kapellakis, I.E.; Tsagarakis, K.P.; Avramaki, C.; Angelakis, A.N. Olive mill wastewater management in river basins: A case study in Greece. Agr. Water Manag. 2006, 82, 354-370.

2. Azbar, N.; Bayram, A.; Filibeli, A.; Muezzinoglu, A.; Sengul, F.; Ozer, A. A review of waste management options in olive oil production. Crit. Rev. Environ. Sci. Technol. 2004, 34, 209-247.

3. Mantzavinos, D.; Kalogerakis, N. Treatment of olive mill effluents: Part I. Organic matter degradation by chemical and biological processes-An overview. Environ. Int. 2005, 31, 289-295.

4. Sabbah, I.; Marsook, T.; Basheer, S. The effect of pretreatment on anaerobic activity of olive mill wastewater using batch and continuous systems. Process Biochem. 2004, 39, 1947-1951.

5. Crites, R.W.; Reed, S.C.; Bastian, R.K. Land Treatment Systems for Municipal and Industrial Wastes; McGraw-Hill: New York, NY, USA, 2008.

6. Grismer, M.E.; Carr, M.A.; Shepherd, H.L. Evaluation of constructed wetland treatment performance for winery wastewater. Water Environ. Res. 2003, 75, 412-421. 
7. Knight, R.L.; Payne, V.W.E., Jr; Borer, R.E.; Clarke, R.A., Jr; Pries, J.H. Constructed wetlands for livestock wastewater management. Ecol. Eng. 2000, 15, 41-55.

8. Vymazal, J. The use constructed wetlands with horizontal sub-surface flow for various types of wastewater. Ecol. Eng. 2009, 35, 1-17.

9. Del Bubba, M.; Checchini, L.; Pifferi, C.; Zanieri, L.; Lepri, L. Olive mill wastewater treatment by a pilot-scale subsurface horizontal flow (SSF-h) constructed wetland. Annali di Chimica 2004, 94, 875-887.

10. Herouvim, E.; Akratos, C.S.; Tekerlekopoulou, A.; Vayenas, D.V. Treatment of olive mill wastewater in pilot-scale vertical flow constructed wetlands. Ecol. Eng. 2011, 37, 931-939.

11. Sohsalam, P.; Sirianuntapiboon, S. Feasibility of using constructed wetland treatment for molasses wastewater treatment. Bioresour. Technol. 2008, 99, 5610-5616.

12. APHA. Standard Methods for the Examination of Water and Wastewater, 20th ed.; American Public Health Association: Washington, DC, USA, 1995.

13. García García, I.; Jiménez Peña, P.R.; Bonilla Venceslada, J.L.; Martín Martín, A.; Martín Santos, M.A.; Ramos Gómez, E. Removal of phenol compounds from olive mill wastewater using Phanerochaete chrysosporium, Aspergillus niger, Aspergillus terreus and Geotrichum candidum. Process Biochem. 2000, 35, 751-758.

14. Niaounakis, M.; halvadakis, C.P. Olive Processing Waste Management: Literature Review and Patent Survey; Pergamon Press: Oxford, UK, 2006.

15. Kadlec, R.H.; Knight, R.L. Treatment Wetlands; CRC Press: Boca Raton, FL, USA, 1996.

16. Ait Ali, N.; Bernal, M.P.; Ater, M. Tolerance and bioaccumulation of cadmium by Phragmites australis grown in the presence of elevated concentrations of Cadmium, Copper, and Zinc. Aquat. Bot. 2004, 80, 163-176.

17. Vasquez, E.A.; Glenn, E.P.; Guntenspergen, G.R.; Brown, J.J.; Nelson, S.G. Salt tolerance and osmotic adjustment of Spartina alterniflora (Poaceae) and the invasive M haplotype of Phragmites australis (Poaceae) along a salinity gradient. Am. J. Bot. 2006, 93, 1784-1790.

18. Vymazal, J.; Kröpfelová, L. Removal of organics in constructed wetlands with horizontal sub-surface flow: A review of the field experience. Sci. Total Environ. 2009, 407, 3911-3922.

19. Abira, M.; van Brugge, J.J.A.; Denny, P. Potential of a tropical subsurface constructed wetland to remove phenol from pre-treated pulp and papermill wastewater. In Proceedings of the 6th International Conference. on Waste Stabilisation Ponds and 9th International. Conference. on Wetland Systems; Avignon, France, 26 September-1 October 2004; pp. 353-358.

20. Montemurro, F.; D. Mariangela; C. Vitti; D. Ferri. Potential use of olive mill wastewater as amendment: Crops yield and soil properties assessment. Commun. Soil Sci. Plant Anal. 2011, 42, 2594-2603.

21. Moraetis, D.; Stamati, F. E.; Nikolaidis, N.P.; Kalogerakis N. Olive mill wastewater irrigation of maize: Impacts on soil and groundwater. Agr. Water Manage. 2011, 98, 1125-1132.

22. El Hassani, F.Z.; Zinedine, A.; Mdaghri Alaoui, S.; Merzouki, M.; Benlemlih, M. Use of olive mill wastewater as an organic amendment for Mentha spicata L. Ind. Crops Prod. 2010, 32, 343-348. 
23. Chartzoulakis, K.; Psarras, G.; Moutsopoulou, M.; Stefanoudaki, E. Application of olive mill wastewater to a Cretan olive orchard: Effects on soil properties, plant performance and the environment. Agr.Ecosyst. Environ. 2010, 138, 293-298.

24. Austin, E.E.; Castro, H.F.; Sides, K.E.; Schadt, C.W.; Classen, A.T. Assessment of 10 years of $\mathrm{CO}_{2}$ fumigation on soil microbial communities and function in a sweetgum plantation. Soil Biol. Biochem. 2009, 41, 514-520.

25. Reed, S.C.; Crites, R.W.; Middlebrooks, E.J. Natural Systems for Waste Management and Treatment, 2nd ed.; McGraw-Hill: New York, NY, USA, 1995.

26. Zhu, G.B; Wang, S.Y.; Feng, X.J.; Fan, G.; Jetten, Mike S.M.; Yin, C.Q. Anammox bacterial abundance, biodiversity and activity in a constructed wetland. Environ. Sci. Technol. 2011, 45, 9951-9958.

27. Zhu, G.; Jetten, M.S.; Kuschk, P.; Ettwig, K.F.; Yin, C. Potential roles of anaerobic ammonium and methane oxidation in the nitrogen cycle of wetland ecosystems. Appl. Microbiol Biotechnol. 2010, 86, 1043-1055.

28. Erler, D. V.; Eyre, B.D.; Davison, L. The contribution of anammox and denitrification to sediment N2 production in a surface flow constructed wetland. Environ. Sci. Technol. 2008, 42, 9144-9150.

29. USA Environmental Protection Agency; USA Environmental Protection Agency Office of Research and Development National Risk Management Research Laboratory. Constructed Wetlands Treatment of Municipal Wastewaters; Diane Publishing: Darby, PA, USA, 2000.

(C) 2012 by the authors; licensee MDPI, Basel, Switzerland. This article is an open access article distributed under the terms and conditions of the Creative Commons Attribution license (http://creativecommons.org/licenses/by/3.0/). 